
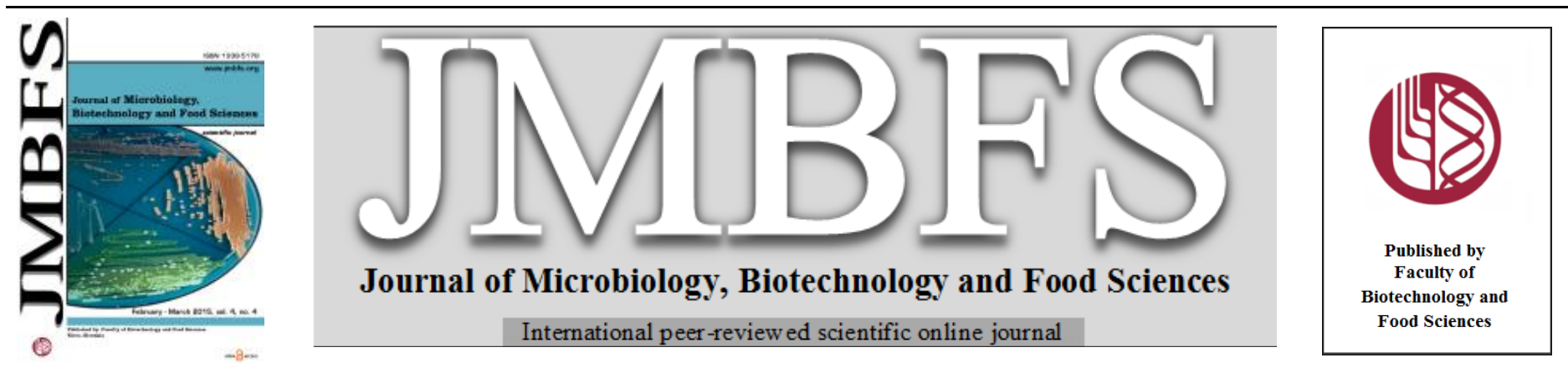

\title{
IN VITRO SUPPLEMENTATION OF RESVERATROL TO BOVINE SPERMATOZOA: EFFECTS ON MOTILITY, VIABILITY AND SUPEROXIDE PRODUCTION
}

\author{
Eva Tvrdá", Norbert Lukáč, Jana Lukáčová, Faridullah Hashim, Peter Massányi
}

Address(es): MSc. Eva Tvrdá, PhD.

${ }^{1}$ Slovak University of Agriculture in Nitra, Faculty of Biotechnology and Food Sciences, Department of Animal Physiology, Tr. A. Hlinku 2, 94976 Nitra, +421 376414288 .

*Corresponding author: evina.tvrda@gmail.com

doi: 10.15414/jmbfs.2015.4.4.336-341

\section{ARTICLE INFO}

Received 23. 11. 2014

Revised 10. 12. 2014

Accepted 10. 12. 2014

Published 1. 2. 2015

Regular article OPEN $\partial_{\text {ACCESS }}$

\begin{abstract}
The aim of this study was to assess the dose- and time dependent in vitro effects of resveratrol (RES), a natural polyphenol and phytoalexin with potential antiviral, anti-inflammatory and antioxidant properties on bovine spermatozoa during five different time periods ( $0 \mathrm{~h}, 2 \mathrm{~h}, 6 \mathrm{~h}, 12 \mathrm{~h}$ and $24 \mathrm{~h})$. Semen samples were collected from 20 adult breeding bulls, and diluted in physiological saline solution containing $0.5 \%$ DMSO together with $0,1,5,10,50,100$ and $200 \mu \mathrm{M} / \mathrm{L}$ RES. Spermatozoa motility was examined using the Sperm Vision $^{\mathrm{TM}}$ and CASA (Computer Assisted Semen Analyzer) system. Cell viability was measured using the metabolic activity MTT assay, the nitroblue-tetrazolium (NBT) test was used to assess the intracellular superoxide formation. The initial CASA analysis showed no significant changes in the spermatozoa motion parameters, however a motion-promoting effect of 10 and $50 \mu \mathrm{M} / \mathrm{L}$ RES became significant after $2 \mathrm{~h}(\mathrm{P}<0.05)$, and maintained this status throughout the in vitro culture $(6 \mathrm{~h}, 12 \mathrm{~h}, 24 \mathrm{~h} ; \mathrm{P}<0.001)$. Meanwhile, both motility parameters were significantly decreased in the group A $(\mathrm{P}<0.001)$ and $\mathrm{B}(\mathrm{P}<0.05)$, supplemented with the highest concentration of RES (200 and $100 \mu \mathrm{M} / \mathrm{L}$ RES; respectively), after a comparison with the control group. According to the MTT assay, instant RES administration (0h) had a significant beneficial effect on the cell viability in the experimental groups supplemented with 10 and $50 \mu \mathrm{M} / \mathrm{L}$ RES. These effects remained visible and statistically relevant $(\mathrm{P}<0.001)$ throughout all MTT examinations. Similar to the CASA analysis, the MTT test revealed an inhibition in the cell viability followed by the administration of 100 and $200 \mu \mathrm{M} / \mathrm{L}$ RES $(\mathrm{P}<0.001)$. Although RES had no immediate effects on the spermatozoa oxidative balance during the in vitro culture, further experiments revealed that the administration of 1-50 $\mu \mathrm{M}$ RES led to a significant decline of the superoxide formation in comparison to the control $(\mathrm{P}<0.001, \mathrm{P}<0.01, \mathrm{P}<0.05$; respectively), while a significant increase in the superoxide concentration was detected following administration of 100 and $200 \mu \mathrm{M}$ RES ( $\mathrm{P}<0.05$ and $\mathrm{P}<0.001$; respectively). The results indicate that the addition of resveratrol, specifically at $5-50 \mu \mathrm{M} / \mathrm{L}$ to the culture medium could be beneficial for the overall stimulation of spermatozoa activity and protection against possible in vitro oxidative stress development.
\end{abstract}

Keywords: Resveratrol, spermatozoa, bulls, motility, viability, oxidative stress

\section{INTRODUCTION}

Uncontrolled overproduction of reactive oxygen species (ROS) followed by oxidative stress (OS) development has become a threat to male fertility (Agarwal et al., 2003). The specific cellular structure of spermatozoa renders them to be particularly vulnerable to oxidative damage. Their plasma membranes contain large quantities of polyunsaturated fatty acids (PUFA), while their cytoplasm contains low concentrations of scavenging enzymes (Tvrdá et al., 2011), leading to increased ROS attacks with a subsequent decrease in motility and viability (de Lamirande and Gagnon, 1992). Oxidative damage often results in increased midpiece morphological defects with deleterious effects on sperm capacitation and acrosome reaction, all of which may ultimately lead to infertility (Agarwal $\boldsymbol{e t}$ al., 2014).

Studies have shown that antioxidant supplementation may protect spermatozoa from ROS sources, directly scavenge ROS, prevent DNA fragmentation, improve semen quality, reduce cryodamage to spermatozoa, block premature sperm maturation and generally stimulate spermatozoa metabolism (Agarwal $\boldsymbol{e t}$ al. 2007). However, the majority of scientific investigations are still uncontrolled, focus on healthy fertile individuals or lead to indirect end-points of success Others are notable for the study design quality, demonstrating compelling evidence in terms of antioxidant efficacy in improving semen parameters (Kefer et al., 2009).

Resveratrol (trans-3,5,4'-trihydroxystilbene; RES) is a natural polyphenol synthesized by a variety of plant species in response to injury, UV irradiation or fungal attack. High RES concentrations are found in grapes, berries, peanuts, as well as red wine (Savouret and Quesne, 2002). Besides well-known cardioprotective effects, RES exhibits anticancer properties against diverse tumor cells, suppressing cell proliferation, promoting apoptotic effects of cytokines, chemotherapeutic agents and ionizing radiation as reviewed by Aggarwal $\boldsymbol{e t}$ al. (2004). In addition of being an antioxidant and a vasorelaxing agent, RES modulates lipoprotein metabolism, inhibits platelet aggregation, and exerts chemopreventive and therapeutic activity. Given the structural similarities of RES to diethylstilbestrol and estradiol, it has been classified as a phytoestrogen (Levenson et al., 2003; Aggarwal et al., 2004).

With respect to male reproduction, some recent in vivo studies in animal models demonstrate that RES administration enhances sperm production in rats by stimulating the hypothalamic-pituitary-gonadal axis without inducing adverse effects (Juan et $\boldsymbol{a l}$., 2003). RES may also have a positive effect by triggering penile erection and enhancing blood testosterone levels, followed by elevated testicular sperm count and epididymal sperm motility (Shin et al., 2008) Protective effects of RES against oxidative damage induced by the cryopreservation of human semen has recently been observed as well (Garcez $\boldsymbol{e t}$ al., 2010).

This study was designed to evaluate the in vitro effects of resveratrol on ejaculated bovine spermatozoa in order to assess possible beneficial or toxic effects of this compound, as well as to define its efficacy for further experiments.

\section{MATERIAL AND METHODS}

Bovine semen samples were obtained from 20 adult breeding bulls (Slovak Biological Services, Nitra, Slovak Republic). The samples had to accomplish the basic criteria given for the corresponding breed. The samples were obtained on a 
regular collection schedule using an artificial vagina. After collection the samples were stored in the laboratory at room temperature $\left(22-25^{\circ} \mathrm{C}\right)$.

Each sample was diluted in physiological saline solution (PS; sodium chloride $0.9 \% \mathrm{w} / \mathrm{v}$; Bieffe Medital, Italia) containing 0.5\% DMSO (Dimethyl sulfoxide Sigma-Aldrich, St. Louis, USA), with various concentrations of RES (SigmaAldrich, St. Louis, USA; A - 200; B - 100; C - 50; D - 10; E - 5; F - $1 \mu \mathrm{M} / \mathrm{L}$ ) using a dilution ratio of 1:40. The samples were cultured at room temperature $\left(22-25^{\circ} \mathrm{C}\right)$. We compared the control (Ctrl) group (medium without RES supplementation) with the experimental groups.

Motility and progressive motility analysis was carried out using the CASA (Computer Assisted Semen Analyzer) system equipped with the SpermVision ${ }^{\mathrm{TM}}$ program (MiniTub, Tiefenbach, Germany) and the Olympus BX 51 microscope (Olympus, Japan) at cultivation Times $0 \mathrm{~h}, 2 \mathrm{~h}, 6 \mathrm{~h}$ (models suitable for a shortterm in vitro culture) as well as $12 \mathrm{~h}$ and $24 \mathrm{~h}$ (models suitable for a long-term in vitro culture). Each sample was placed into the Makler Counting Chamber (depth $10 \mu \mathrm{m}$, Sefi-Medical Instruments, Israel) and the percentage of motile (motility > $5 \mu \mathrm{m} / \mathrm{s} ;$ MOT) and progressively motile spermatozoa (motility $>20 \mu \mathrm{m} / \mathrm{s} ;$ PROG) was evaluated. 1000-1500 cells were assessed in each analysis (Massanyi et al., 2008)

Viability of the cells exposed to RES in vitro was evaluated by the metabolic activity (MTT) assay (Mosmann, 1983; Knazicka et al., 2012). This colorimetric assay measures the conversion of 3-(4,5-dimetylthiazol-2-yl)-2,5diphenyltetrazolium bromide (MTT; Sigma-Aldrich, St. Louis, USA) to purple formazan particles by mitochondrial succinate dehydrogenase of intact mitochondria of living cells. Formazan can then be measured spectrophotometrically at a measuring wavelength of $570 \mathrm{~nm}$ against $620 \mathrm{~nm}$ as reference by a microplate ELISA reader (Multiskan FC, ThermoFisher Scientific, Finland). The data are expressed in percentage of control (i.e. optical density of formazan from cells not exposed to RES). Results from the analysis were collected during five repeated experiments at each concentration.

The nitroblue-tetrazolium (NBT) test was used to assess the intracellular formation of superoxide radical (Esfandiari et al., 2003). This assay is conducted by counting the cells containing blue NBT formazan deposits, which are formed by reduction of the membrane permeable, water-soluble, yellow-colored, nitroblue tetrazolium chloride (2,2'-bis(4-Nitrophenyl)-5,5'-diphenyl-3,3'-(3,3'dimethoxy-4,4'-diphenylene)ditetrazolium chloride; Sigma-Aldrich, St. Louis, USA) and superoxide radical. Formazan can be measured spectrophotometrically at a measuring wavelength of $620 \mathrm{~nm}$ against $570 \mathrm{~nm}$ as reference by a microplate ELISA reader (Multiskan FC, ThermoFisher Scientific, Finland). The data were expressed in percentage of control (i.e. optical density of formazan from cells not exposed to RES). Results from the analysis were collected during five repeated experiments at each concentration (Tvrdá et al., 2013).

Statistical analysis was carried out using the GraphPad Prism program (version 3.02 for Windows; GraphPad Software, La Jolla California USA www.graphpad.com). Descriptive statistical characteristics (mean, standard error) were evaluated at first. One-way ANOVA with Dunnett's post test was used for statistical evaluations. The level of significance was set at ${ }^{* * *}(\mathrm{P}<0.001)$; ** $(\mathrm{P}<0.01) ; *(\mathrm{P}<0.05)$

\section{RESULTS AND DISCUSSION}

The CASA assessment showed a continuous decrease of spermatozoa motility and progressive motility in all groups over the course of a $24 \mathrm{~h}$ in vitro culture (Table 1, Table 2). The initial (Time 0h) MOT and PROG were higher in the experimental groups C (50 $\mu \mathrm{M} / \mathrm{L}$ RES $), \mathrm{D}(10 \mu \mathrm{M} / \mathrm{L}$ RES $)$ and $\mathrm{E}(5 \mu \mathrm{M} / \mathrm{L}$ RES $)$ when compared to the control group $(0 \mu \mathrm{M} / \mathrm{L}$ RES $)$, although without any statistical significance $(\mathrm{P}>0.05)$. Even statistically insignificant, a motionpromoting effect of RES remained notable after $2 \mathrm{~h}$, specifically in the groups $\mathrm{C}$ and $\mathrm{E}$. Meanwhile, a significantly higher $(\mathrm{P}<0.05)$ MOT as well as PROG were detected in the group D. Furthermore, $200 \mu \mathrm{M} / \mathrm{L}$ RES (group A) and $100 \mu \mathrm{M} / \mathrm{L}$ RES (group B) caused a non-significant decrease of the spermatozoa motility characteristics $(\mathrm{P}<0.05)$. After $6 \mathrm{~h}$, the decline of spermatozoa MOT as well as PROG were significantly decreased in the group A $(\mathrm{P}<0.001)$ in comparison with the control. Examination at $12 \mathrm{~h}$ of in vitro culture showed that the spermatozoa motility and progressive motility were significantly increased in groups $\mathrm{C}$ $(\mathrm{P}<0.001)$ and $\mathrm{D} \quad(\mathrm{P}<0.001)$ when compared to the control. Moreover significantly decreased motion parameters were detected in groups $\mathrm{A}$ as well as $\mathrm{B}$ $(\mathrm{P}<0.001)$ in comparison to the control. At the end of the experiments $(24 \mathrm{~h})$ elevated motility parameters were observed in the experimental groups supplemented with $50-1 \mu \mathrm{M} / \mathrm{L}$ RES (experimental groups $\mathrm{C}-\mathrm{F}$ ), being significantly higher in comparison with the control $(\mathrm{P}<0.001)$. Meanwhile, both MOT as well as PROG were significantly decreased in the group A $(\mathrm{P}<0.001)$ and $\mathrm{B}(\mathrm{P}<0.05)$, supplemented with the highest concentration of RES (200 and $100 \mu \mathrm{M} / \mathrm{L}$ RES; respectively), after a comparison with the Ctrl group (Table 1 , Table 2).

$\underline{\text { Table } 1 \text { Spermatozoa motility (\%) in the absence (Ctrl) or presence (A-F) of resveratrol during different time periods (Mean } \pm \text { SEM; } n=20)}$

\begin{tabular}{|c|c|c|c|c|c|c|c|}
\hline Groups & Ctrl & $\mathbf{A}$ & B & C & D & $\mathbf{E}$ & $\mathbf{F}$ \\
\hline \multicolumn{8}{|c|}{ Time $0 \mathrm{~h}$} \\
\hline & $85.97 \pm 2.35$ & $81.04 \pm 0.83$ & $82.07 \pm 1.95$ & $91.33 \pm 2.53$ & $92.55 \pm 3.40$ & $88.50 \pm 1.46$ & $85.26 \pm 3.83$ \\
\hline \multicolumn{8}{|c|}{ Time $2 \mathrm{~h}$} \\
\hline & $81.46 \pm 3.07$ & $78.61 \pm 2.43$ & $79.59 \pm 2.71$ & $86.66 \pm 3.31$ & $87.85 \pm 4.02^{*}$ & $83.75 \pm 2.57$ & $80.76 \pm 2.29$ \\
\hline \multicolumn{8}{|c|}{ Time 6 h } \\
\hline & $66.10 \pm 1.50$ & $39.61 \pm 2.09^{* * *}$ & $62.24 \pm 1.79$ & $80.97 \pm 2.09^{* * * *}$ & $83.84 \pm 2.93^{* * *}$ & $73.96 \pm 1.56$ & $70.85 \pm 3.09$ \\
\hline \multicolumn{8}{|c|}{ Time $12 \mathrm{~h}$} \\
\hline & $53.09 \pm 1.62$ & $22.98 \pm 2.31^{* * *}$ & $40.51 \pm 1.96^{* * 2 \times 1}$ & $70.05 \pm 2.76^{* * *}$ & $75.48 \pm 2.54^{* * * *}$ & $62.00 \pm 2.23$ & $60.64 \pm 3.41$ \\
\hline \multicolumn{8}{|c|}{ Time $24 \mathrm{~h}$} \\
\hline & $40.69 \pm 3.07$ & $7.91 \pm 0.54^{* * * *}$ & $25.65 \pm 2.31^{*}$ & $63.09 \pm 2.58^{* * *}$ & $66.69 \pm 2.00^{* * *}$ & $55.17 \pm 1.78^{* * *}$ & $50.99 \pm 2.83^{\text {*** }}$ \\
\hline
\end{tabular}

\begin{tabular}{|c|c|c|c|c|c|c|c|}
\hline Groups & Ctrl & $\mathbf{A}$ & B & $\mathbf{C}$ & $\mathbf{D}$ & $\mathbf{E}$ & $\mathbf{F}$ \\
\hline \multicolumn{8}{|c|}{ Time 0h } \\
\hline & $77.90 \pm 2.25$ & $72.09 \pm 0.99$ & $76.09 \pm 1.77$ & $82.39 \pm 2.13$ & $81.56 \pm 2.40$ & $79.00 \pm 1.55$ & $76.27 \pm 2.95$ \\
\hline \multicolumn{8}{|c|}{ Time $2 \mathrm{~h}$} \\
\hline & $72.41 \pm 3.01$ & $69.61 \pm 1.53$ & $70.22 \pm 2.11$ & $75.81 \pm 3.00$ & $77.89 \pm 3.05^{*}$ & $74.55 \pm 2.07$ & $71.47 \pm 1.99$ \\
\hline \multicolumn{8}{|c|}{ Time $6 \mathrm{~h}$} \\
\hline & $58.18 \pm 1.80$ & $31.99 \pm 2.02^{* * *}$ & $51.17 \pm 1.25$ & $70.99 \pm 2.01^{* * * *}$ & $72.60 \pm 2.33^{* * *}$ & $64.66 \pm 1.06$ & $61.15 \pm 3.00$ \\
\hline \multicolumn{8}{|c|}{ Time $12 \mathrm{~h}$} \\
\hline & $45.59 \pm 1.47$ & $18.88 \pm 2.01^{* * *}$ & $32.11 \pm 1.06^{k * * \pi}$ & $61.15 \pm 2.66^{* * * *}$ & $64.84 \pm 2.14^{* * * *}$ & $57.09 \pm 2.01$ & $51.24 \pm 2.40$ \\
\hline \multicolumn{8}{|c|}{$\begin{array}{ll}\text { Time } 24 \mathrm{~h} \\
\end{array}$} \\
\hline & $32.47 \pm 1.65$ & $2.08 \pm 1.44^{* * * *}$ & $16.35 \pm 2.51^{*}$ & $52.99 \pm 1.01^{* * *}$ & $49.89 \pm 1.80^{* * * *}$ & $44.71 \pm 1.84^{* * * *}$ & $42.89 \pm 2.05^{\text {*** }}$ \\
\hline
\end{tabular}

According to the MTT assay, instant RES administration (Time 0h) had a significant beneficial effect on the cell viability in the experimental groups $\mathrm{C}$ and $\mathrm{D}(\mathrm{P}<0.001$; Figure 1$)$. Investigation at $2 \mathrm{~h}$ confirmed the previous observations with significant effects $(\mathrm{P}<0.001)$ in groups $\mathrm{C}$ and $\mathrm{D}$. Beneficial effects of 50 and $10 \mu \mathrm{M} / \mathrm{L}$ RES (experimental groups $\mathrm{C}$ and $\mathrm{D}$ ) remained visible and statistically relevant throughout the entire in vitro culture, as shown in Figure 1 (Time 6h,
Time $12 \mathrm{~h}$, Time 24h; $\mathrm{P}<0.001)$. Similar to the CASA analysis, the MTT test revealed an inhibition in the cell viability followed by the administration of 200 $\mu \mathrm{M} / \mathrm{L}$ RES (groups A), starting to be notable at $2 \mathrm{~h}(\mathrm{P}>0.05$ ), and followed by statistically significant differences at Times $6 \mathrm{~h}(\mathrm{P}<0.05), 12 \mathrm{~h}(\mathrm{P}<0.001)$ and $24 \mathrm{~h}$ $(\mathrm{P}<0.001)$. Moreover, significant cytotoxic effects of $100 \mu \mathrm{M} / \mathrm{L}$ RES were recorded at Time $24 \mathrm{~h}(\mathrm{P}<0.001$; Figure 1$)$ 
MTT Oh

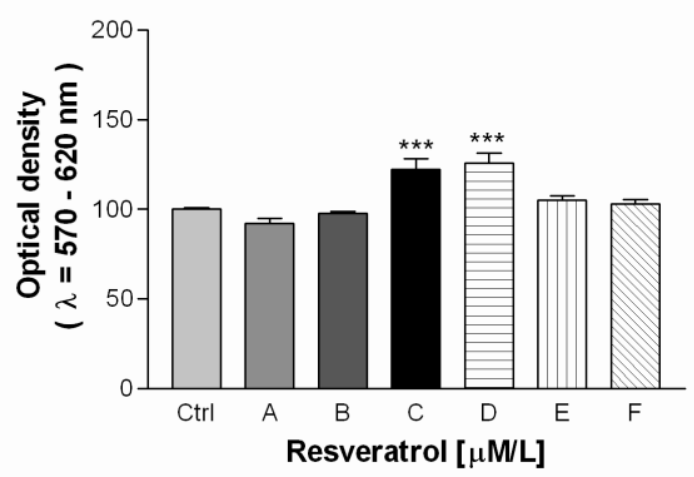

MTT 6h

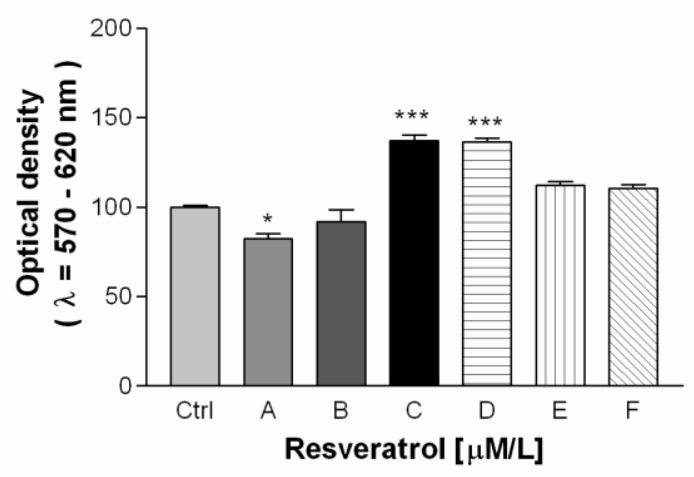

MTT 24h

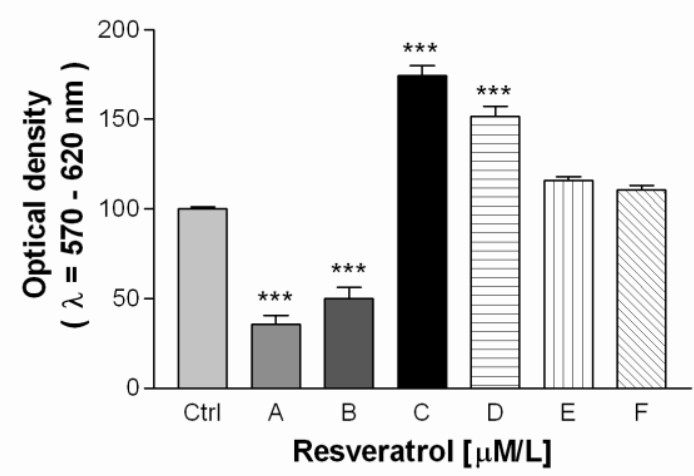

MTT 2h

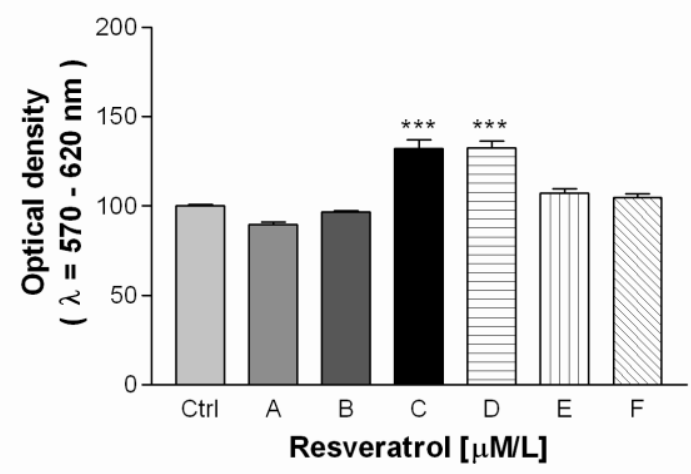

MTT 12h

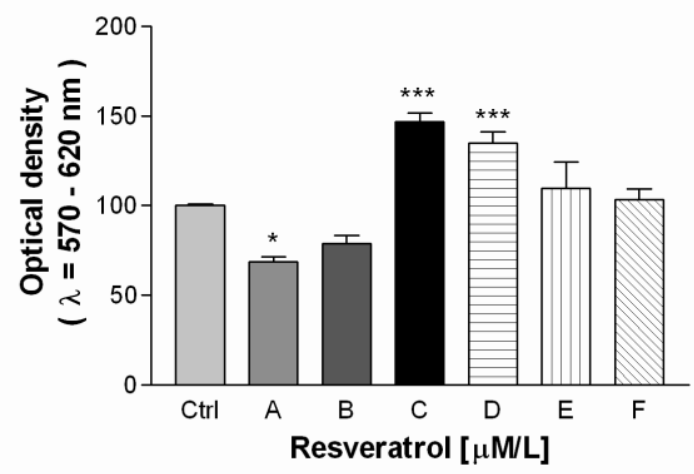

Figure 1 The effect of various doses of resveratrol on the viability of bovine spermatozoa $(\mathrm{n}=20)$ at $0 \mathrm{~h}, 2 \mathrm{~h}, 6 \mathrm{~h}, 12 \mathrm{~h}$ and $24 \mathrm{~h}$. Each bar represents mean $( \pm \mathrm{SEM})$ optical density as the percentage of controls, which symbolize $100 \%$. The data were obtained from five independent experiments. The level of significance was set at ${ }^{* * *} \mathrm{P}<0.001 ;{ }^{* *} \mathrm{P}<0.01 ;{ }^{*} \mathrm{P}<0.05$. Ctrl $-0 ; \mathrm{A}-200 ; \mathrm{B}-100 ; \mathrm{C}-$ $50 ; \mathrm{D}-10 ; \mathrm{E}-5 ; \mathrm{F}-1 \mu \mathrm{M} / \mathrm{L}$ RES.

Although RES had no immediate effects on the spermatozoa oxidative balance during the in vitro culture ( $\mathrm{P}>0.05$; Figure 2$)$, experiments following a $2 \mathrm{~h}$ revealed that the administration of $50 \mu \mathrm{M}$ RES led to a significant decline of the superoxide formation in comparison to the Control $(\mathrm{P}<0.05)$, while a significant increase in the superoxide concentration was detected in the experimental group A, administered with $200 \mu \mathrm{M}$ RES $(\mathrm{P}<0.05)$. Beginning at $6 \mathrm{~h}$ and following the entire in vitro incubation it was shown that RES concentrations ranging from 200 to $100 \mu \mathrm{M}$ (groups $\mathrm{A}$ and $\mathrm{B}$ ) exhibited a long-term and statistically significant $(\mathrm{P}<0.001)$ cytotoxic effects on the male germ cells followed by a subsequent promotion of the escalating intracellular superoxide production, considered to be the first step in the creation of oxidative stress (Figure 2). On the other hand lower RES concentrations exhibited notable protective effects on the sperm cell structures vulnerable to the escalating superoxide production, which became increasingly significant, correspondingly to the growing timeframe of the in vitro culture $(\mathrm{P}<0.01$ in case of group $\mathrm{C}$ and $\mathrm{P}<0.05$ in case of group $\mathrm{D}$ at Time 6h; $\mathrm{P}<0.001$ in case of group $\mathrm{C}, \mathrm{P}<0.01$ in case of group $\mathrm{D}$ and $\mathrm{P}<0.05$ in case of group $\mathrm{E}$ at Time $12 \mathrm{~h} ; \mathrm{P}<0.001$ in groups $\mathrm{C}$ and $\mathrm{D}, \mathrm{P}<0.01$ in case of group $\mathrm{E}$ and $\mathrm{P}<0.05$ in case of group $\mathrm{F}$ at Time 24h; Figure 2). 
NBT Oh

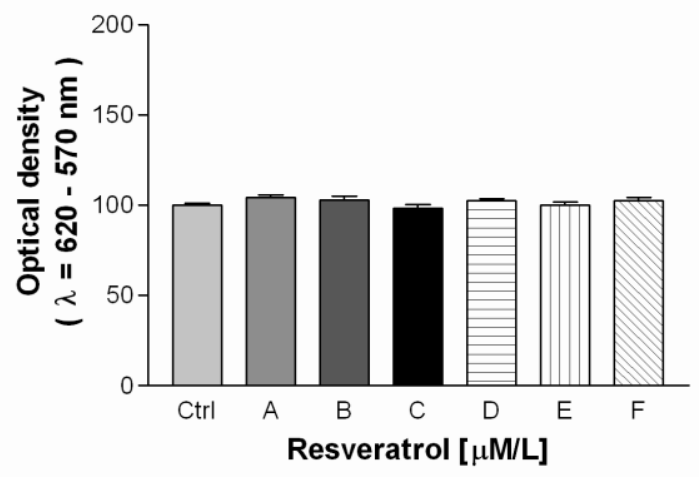

NBT $6 h$

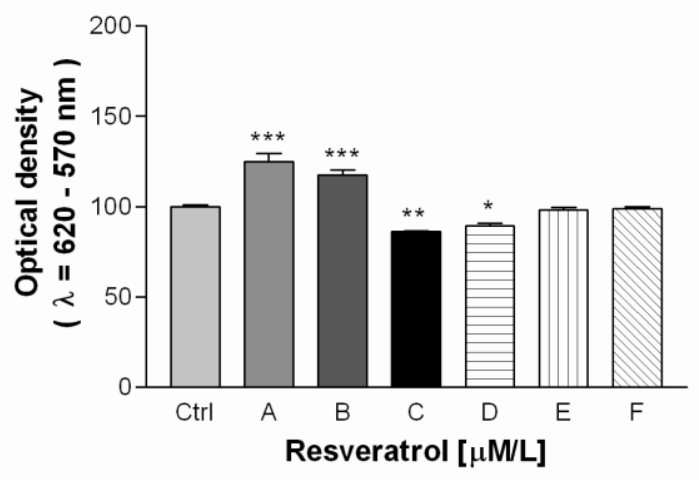

NBT 24h

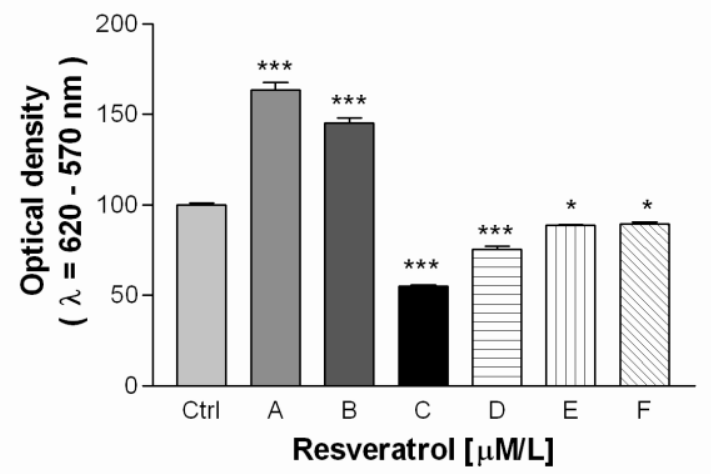

NBT 2h

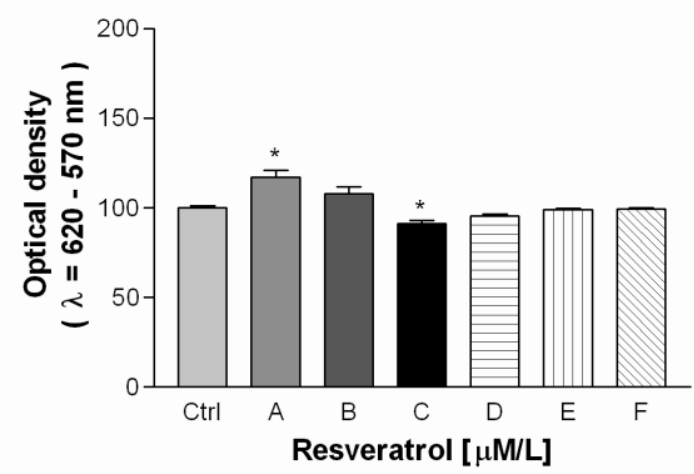

NBT 12h

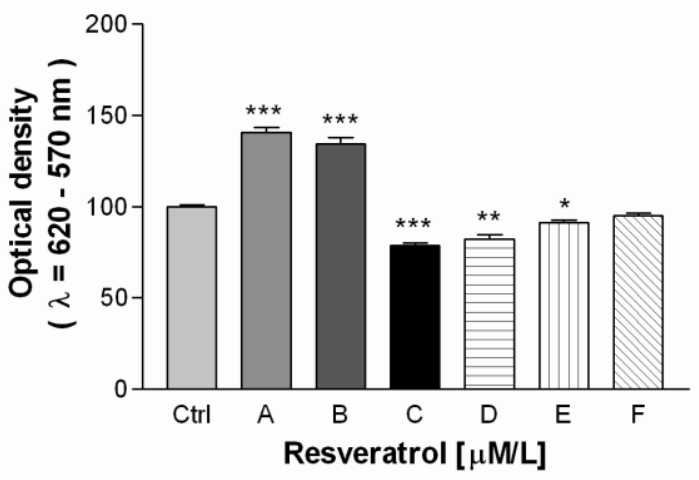

Figure 2 The effect of various doses of resveratrol on the spermatozoa $(\mathrm{n}=20)$ superoxide production at $0 \mathrm{~h}, 2 \mathrm{~h}, 6 \mathrm{~h} 12 \mathrm{~h}$ and $24 \mathrm{~h}$. Each bar represents the mean $( \pm$ SEM) optical density as the percentage of controls, which symbolize $100 \%$. The data were obtained from five independent experiments. The level of significance was set at ${ }^{* * *} \mathrm{P}<0.001 ;{ }^{* *} \mathrm{P}<0.01 ;{ }^{*} \mathrm{P}<0.05$. Ctrl $-0 ; \mathrm{A}-200 ; \mathrm{B}-100 ; \mathrm{C}-50 ; \mathrm{D}-10 ; \mathrm{E}-5 ; \mathrm{F}-1 \mu \mathrm{M} / \mathrm{L}$ RES.

Over the past years, RES has emerged as a complex biologically active agent. Due to its remarkably broad range of effects, especially with respect to cardiovascular, anticancer, antiinflamatory protection and longevity, RES has attracted a widespread scientific and consumer interest (Calabrese et al., 2010).

According to numerous studies, RES is well absorbed and rapidly metabolized, furthermore it seems to be well tolerated and no distinct toxicity was reported (Cottart et al., 2010). However, substantial in vitro experiments show, that RES has a dose-dependent activity on the cultured cells. This molecule displays an important dichotomy: low doses improve cell survival, yet high doses increase cell death (Brown et al., 2009).

Forgacs et al. (2005) examined the effect of various RES concentrations on the viability and activity of mouse Leydig cells. RES cytotoxicity appeared at 200 $\mu \mathrm{M} / \mathrm{L}$. The basal testosterone level showed a mild, but a significant increase in the presence of 12.5-50 $\mu \mathrm{M} / \mathrm{L}$ RES. Interestingly, RES had a biphasic effect on the human chorionic gonadotropin (hCG) simulated testosterone production. The results showed that RES had a small additive effect at lower concentrations (3 $\mu \mathrm{M})$ whereas at higher concentrations $(>25 \mu \mathrm{M})$ it turned to be an inhibitor of the testosterone production. Similar effects were observed by Juan $\boldsymbol{e t}$ al. (2005) in his in vivo experiments, where RES administration led to increased serum testosterone. Based on the presumptions of the authors, a possible mechanism of action could be connected to the LH (luteinizing hormone) receptor. Since RES is an estrogen-like molecule, there is another hypothesis assumes that RES modifies the hCG-LH response through estrogen receptors (Levenson et al., 2003; Aggarwal et al., 2004). The studies conclude, that RES has an additive effect (at low concentration) to the hCG stimulated testosterone production and suggest that RES may take advantage of an alternative route to the LH-receptor mediated pathway, connected to the receptor-cross-talking or an LH-receptor independent increase of the cAMP-levels.

The aim of our study was to analyze the effects of RES on the bovine spermatozoa viability and free radical production in vitro. Our results agree with Collodel et al. (2010) evaluating the effects of RES on human spermatozoa and rat germinal cells. $100 \mu \mathrm{M} / \mathrm{L}$ RES exerted cytotoxic activities against both cell models acting in a dose dependent manner. The LD50 for both models was identified as $50 \mu \mathrm{M} / \mathrm{L}$, spermatocytes were more sensitive to the harmful effect of RES with a LD50 between 50 and $30 \mu \mathrm{M} / \mathrm{L}$. Moreover, at $100 \mu \mathrm{M} / \mathrm{L}$ the motility was absent in all analyzed samples. Progressive motility reached high values 
between 6 and $15 \mu \mathrm{M} / \mathrm{L}$ RES. In our case, RES concentrations of 200 and 100 $\mu \mathrm{M} / \mathrm{L}$ had inhibiting effects on the spermatozoa activity. $200 \mu \mathrm{M} / \mathrm{L}$ RES induced a significant decrease of the motility together with a significant increase of the superoxide formation. $100 \mu \mathrm{M} / \mathrm{L}$ RES had similar effects, although less radical. Even though the exact mechanism of RES toxicity has not been defined yet, elevated concentrations of this biomolecule were shown to inhibit the F1 complex of the F0/F1-ATPase proton pump of the mitochondrial inner membrane, responsible for the ATP synthesis within the oxidative phosphorylation pathway (Zheng and Ramirez, 2000). Since mitochondria are specialized organelles for the aerobic production of energy and bear a central role in the cells and tissues with high metabolic activity (Lagouge et al., 2006), it is not surprising that their disfunction leads to a decrease of spermatozoa viability. Furthermore, the ability of RES to interfere with the machinery of mitochondria electron transport could be partially responsible for the depolarization of the mitochondrial membranes followed by apoptosis (Shaman et al., 2006). The most probable apoptotic path activated in this case could be the type II pathway associated with the activation of caspase-9 independently of Fas signaling (Dorrie et al., 2001) or via a novel mitochondrial mechanism controlled by Bcl-2 (Tinhofer et al., 2001).

Interesting results were obtained, when the RES concentration reached 200 $\mu \mathrm{M} / \mathrm{L}$. All viability markers of bovine spermatozoa decreased significantly immediately after the semen samples were diluted in the experimental medium. In this case, it is evident that the RES toxicity could not be explained by a molecular mechanism, since the timeframe for specific interactions between RES and cellular structures was too short. However, we did note that the spermatozoa present in this experimental medium had coiled tails, which, together with a severely impaired viability, are signs of the osmotic shock (Khan and Ijaz, 2008). Based on this observations we may assume that RES concentration of 200 $\mu \mathrm{M} / \mathrm{L}$, besides being toxic, changes the osmotic pressure of the medium, which subsequently leads to an altered plasma membrane integrity and a decreased viability of spermatozoa

In addition to the cytotoxic effects of high RES concentrations, our results revealed a significant stimulation of all the spermatozoa vitality parameters when the concentrations of RES varied between 50 and $5 \mu \mathrm{M} / \mathrm{L}$. Based on these results we may conclude that lower concentrations of RES have beneficial effects on the overall spermatozoa viability and antioxidant status. This conclusion is supported by a large body of evidence from in vitro and in vivo studies indicating that RES may be favorable to a variety of health aspects. One of the most notable biological properties of RES is its antioxidant potential, since it is able to reach peroxidized rigid membranes and increase the membrane fluidity in order to interact more efficiently with radicals in the altered lipid bilayer (Brittes $\boldsymbol{e t}$ al. 2010). Therefore, RES exhibits protective effects against lipid peroxidation in cell membranes and DNA damage caused by ROS (Frèmont, 2000) Additionally, Lagouge et al. (2006) showed that the effects of small RES concentrations were associated in with an induction of genes responsible for oxidative phosphorylation and mitochondrial biogenesis, therefore stimulating mitochondrial functions of the cell, from what we may conclude that low concentrations of RES, besides from acting as an antioxidant, could mobilize the spermatozoa energetic metabolism and therefore improve spermatozoa viability.

\section{CONCLUSIONS}

Our results, even though being preliminary, support the evidence for the dose dependent in vitro activity and the scavenger potential of low resveratro concentrations against oxidative stress induced in bovine spermatozoa. The development of new spermatozoa culture media that can better protect sperm from the oxidative damage and improve their energy requirements is absolutely necessary. Resveratrol, in small amounts, could be used as a ROS scavenging and a metabolic promoting supplement, especially in routine andrology techniques such as in vitro fertilization, artificial insemination or spermatozoa cryopreservation. These results obviously cannot foresee an in vivo outcome, since a direct impact of resveratrol supplementation on male infertility needs to be explored. To translate this findings into clinical reality, studies on the potential toxicity, pharmacokinetics and bioavailability of resveratrol in the organism are definitely needed.

Acknowledgments: This work was co-funded by the European Community under the Project no. 26220220180: Building Research Centre „AgroBioTech", the Scientific Grant Agency of the Ministry of Education of the Slovak Republic and of the Slovak Academy of Sciences VEGA Project no. 1/0857/14 and by the Slovak Research and Development Agency Grant no. APVV-0304-12.

\section{REFERENCES}

AGARWAL, A., PRABAKARAN, S.A., SIKKA S.C. 2007. Clinical relevance of oxidative stress in patients with male factor infertility: evidence-based analysis. AUA Update Series, 26, 1-12. http://dx.doi.org/10.1111/j.16000897.2007.00559.x.
AGARWAL, A., SALEH, R.A., BEDAIWY, M.A. 2003. Role of reactive oxygen species in the patophysiology of human reproduction. Fertility and Sterility, 79, 829-843. http://dx.doi.org/10.1016/S0015-0282(02)04948-8.

AGARWAL, A., TVRDA, E., SHARMA, R. 2014. Relationship amongst teratozoospermia, seminal oxidative stress and male infertility. Reproductive Biology and Endocrinology, 12, 45. http://dx.doi.org/10.1186/1477-7827-12-45. AGGARWAL, B.B., BHARDWAJ, A., AGGARWAL, R.S., SEERAM, N.P., SHISHODIA, S., TAKADA Y. 2004. Role of resveratrol in prevention and therapy of cancer: preclinical and clinical studies. Anticancer Research, 24, 2783-2840.

BRITTES, J., LÚCIO, M., NUNES, C., LIMA, J.L.,REIS, S. 2010. Effects of resveratrol on membrane biophysical properties: relevance for its pharmacological effects. Chemistry and Physics of Lipids, 163(8), 747-754. http://dx.doi.org/ 10.1016/j.chemphyslip.2010.07.004.

BROWN, L., KROON, P.A., DAS, D.K., DAS, S., TOSAKI, A., CHAN, V. 2009. The biological responses to resveratrol and other polyphenols from alcoholic beverages. Alcoholism: Clinical \& Experimental Research, 33, 1513 23. http://dx.doi.org/10.1158/0008-5472.

CALABRESE, E.J., MATTSON, M.P., CALABRESE, V. 2010. Dose response biology: the case of resveratrol. Human Experimental Toxicology, 29(12), 1034 1037. http://dx.doi.org/10.1177/0960327110383625

COLLODEL G., FEDERICO M.G., GEMINIANI M., MARTINI S., BONECHI C., ROSSI C., FIGURA N., MORETTI E. 2010. Effect of trans-resveratrol on induced oxidative stress in human sperm and in rat germinal cells. Reproductive Toxicology, 31(2), 239-246. http://dx.doi.org/10.1016/j.reprotox.2010.11.010. COTTARD, CH.-H., ANTOINE, V. N., LAGUILLIER-MORIZOT, CH., BEAUDEUX, J. L. 2010. Resveratrol bioavailability and toxicity in human. Molecular Nutrition \& Food Research, 54:7-16. http://dx.doi.org/ 10.1002/mnfr.200900437.

DE LAMIRANDE, E. - GAGNON, C. 1993. Human sperm hyperactivation and capacitation as parts of an oxidative process. Free Radicals in Biology and Medicine, 14, 157-166. http://dx.doi.org/10.1016/0891-5849(93)90006-G.

DORRIE, J., GERAUER, H., WACHTER, Y., ZUNINO, S.J. 2001. Resveratrol induces extensive apoptosis by depolarizing mitochondrial membranes and activating caspase-9 in acute lymphoblastic leukemia cells. Cancer Research, 61, 4731-4739.

ESFANDIARI, N., SHARMA, R.K., SHARMA, R.K., SALEH, R.S., THOMAS Jr., A.J., AGARWAL, A. 2003. Utility of the nitroblue tetrazolium reduction test for assessment of reactive oxygen species production by seminal leukocytes and $\begin{array}{lll}\text { spermatozoa. Journal of Andrology, 24(6), 862-870. } & \text {. }\end{array}$ http://dx.doi.org/10.1002/j.1939-4640.2003.tb03137.x.

FORGACS, ZS., SOMOSY, Z., TELBISZ, A., MASSANYI, P., LUKAC, N. 2005. Effect of resveratrol on the testosterone production of mouse primary leydig cell culture. Celoslovensky Seminar z Fyziologie Zivocichov (Proceedings of the International Scientific Conference) Nitra:SUA, 18-24.

FRÈMONT, L. 2000. Biological effects of resveratrol. Life Sciences, 66, 663 673. http://dx.doi.org/10.1089/152308601317203567

GARCEZ, M.E., BRANCO, C.D., LARA, L.V., PASQUALOTTO, F.F., SALVADOR, M. 2010. Effects of resveratrol supplementation on cryopreservation medium of human semen. Fertility and Sterility, 94(6), 2118 2121. http://dx.doi.org/ 10.1016/j.fertnstert.2010.01.058

JUAN, E., GONZÁlES-PONS, E., MUNUERA, T., BALLESTER, J., RODRÍGUEZ-GIL, J. E., PLANAS, J. M. 2005. Trans-resveratrol, a natural antioxidant from grapes, increases sperm output in healthy rats. Journal of Nutrition, 135, 757-760

KEFER, J.C., AGARWAL, A., SABANEGH, E. 2009. Role of antioxidants in the treatment of male infertility. International Journal of Urology, 16, 449-457. http://dx.doi.org/10.1111/j.1442-2042.2009.02280.x.

KHAN, M.I.R., IJAZ, A. 2008. Effects of osmotic pressure on motility, plasma membrane integrity and viability in fresh and frozen-thawed buffalo spermatozoa. Animal http://dx.doi.org/10.1017/S1751731108001596.

KNAZICKA, Z., TVRDA, E., BARDOS, L., LUKAC, N. 2012. Dose- and timedependent effect of copper ions on the viability of bull spermatozoa in different media. In Journal of Environmental Science and Health Part A, 47, 1294-1300. http://dx.doi.org/10.1080/10934529.2012.672135.

LAGOUGE, M., ARGMANN, C., GERHART-HINES, Z., MEZIANE, H., LERIN, C., DAUSSIN, D., MESSADEQ, D., MILNE, J., LAMBERT, P., ELLIOTT, P., GENY, B., LAAKSO, M., PUIGSERVER, P., AUWERX ,J 2006. Resveratrol improves mitochondrial function and protects agains metabolic disease by activating SIRT1 and PGC-1 $\alpha$. Cell, 127(6), 1109-1122. http://dx.doi.org/10.1016/j.cell.2006.11.013.

LEVENSON, A.S., GEHM, B.D., PEARCE, S.T., HORIGUCHI, J., SIMONS L.A., WARD, J.E., JAMESON, J.L., JORDAN, V.C. 2003. Resveratrol acts as an estrogen receptor (ER) agonist in breast cancer cells stably transfected with ER alpha. International Journal of Cancer, 104, 587-596. http://dx.doi.org/10.1002/ijc.10992.

MASSANYI, P., CHRENEK, N., LUKÁČ, N., MAKAREVICH, A.V., OSTRO, A., ŽIVČAK, J., BULLA, J. 2008. Comparison of different evaluation chambers 
for analysis of rabbit spermatozoa motility using CASA system. Slovak Journal of Animal Science, 41, 2008, 60-66.

MOSMANN, T. 1983. Rapid colorimetric assay for cellular growth and surrival: application to proliferation and cytotoxicity assays. Journal of Immunological Methods, 65, 55-63. http://dx.doi.org/10.1016/0022-1759(83)90303-4.

SAVOURET J. F., QUESNE M. 2002. Resveratrol and cancer: a review. Biomedicine \& Pharmacotherapy, 56(2), 84-87. http://dx.doi.org/10.1016/S07533322(01)00158-5

SHAMAN, J.A., YAMAUCHI, Y., WARD, W.S. 2006. Sperm DNA fragmentation: awakening the sleeping genome. Biochemical Society Transactions, 35, 626-628. http://dx.doi.org/10.1042/BST0350626.

SHIN S., JEON J.H., PARK D., JANG M.J., CHOI J.H., CHOI B.H. 2008

Trans-resveratrol relaxes the corpus cavernosum ex vivo and enhances testosterone levels and sperm quality in vivo. Archives of Pharmacal Research 31: 83-87. http://dx.doi.org/10.1007/s12272-008-1124-7.

TINHOFER, I., BERNHARD, D., SENFTER, M., ANETHER, G., LOEFFLER, M., KROEMER, G., KOFLER, R., CSORDAS, A., GREIL, R. 2001. Resveratrol, a tumor-suppressive compound from grapes, induces apoptosis via a novel mitochondrial pathway controlled by Bcl-2. The FASEB Journal, 15, 1613 1615. http://dx.doi.org/10.1096/fj.00 - 0675fje.

TVRDÁ, E., KŇAŽICKÁ, Z., BÁRDOS, L., MASSÁNYI, P., LUKÁČ, N. 2011 Impact of oxidative stress on male fertility - a review. Acta Veterinaria Hungarica, 59(4), 465-484. http://dx.doi.org/10.1556/AVet.2011.034.

TVRDÁ, E., LUKÁČ, N., LUKÁČOVÁ, J., KŇAŽICKÁ, Z., MASSÁNYI, P. 2013. Stimulating and protective effects of vitamin $E$ on bovine spermatozoa Journal of Microbiology, Biotechnology and Food Sciences, 2(1), 1386-1395. ZHENG, J., RAMIREZ, V. D. 2000. Inhibition of mitochondrial proton F0F1ATPase/ATP synthase by polyphenolic phytochemicals. Bazilian Journal of Pharmacology, 130(5), 1115-1123. http://dx.doi.org/10.1038/sj.bjp.0703397. 